\title{
Intracellular parasites of unknown taxonomic position in gills of common carp Cyprinus carpio
}

\author{
Jiři Lom, Iva Dyková \\ Institute of Parasitology, Academy of Sciences of the Czech Republic, Branišovská 31, 37005 Ceské Budějovice, Czech Republic
}

\begin{abstract}
In the gill filaments of common carp Cyprinus carpio fingerlings heavily infected with Sphaerospora molnari intracellular parasites of unknown taxonomic position were detected with TEM. Cells, up to $3.5 \mu \mathrm{m}$ in size, displayed surface projections which were often microvillous in shape. One or more nuclei often in diplokaryon arrangement were seen in sectioned cells. Except for numerous dense bodies, no cytoplasmic organelles were observed. The possible relation to amphizoic amoebae, haplosporidia, microsporidia and myxosporean stages is discussed; these parasites could not be identified with any of the them
\end{abstract}

While studying the ultrastructure of the myxosporean Sphaerospora molnari Lom, Dyková, Pavlásková and Grupcheva, 1983 in the gills of common carp Cyprinus carpio fingerlings we came across parasitic cells which looked completely different from stages of the sporogonic cycle of $S$. molnari. We hesitated to publish these rather enigmatic findings. However, as we have not encountered these stages since, we have decided to present our observations in order to draw attention of future investigators to these organisms.

Material and methods. Small pieces of carp fingerling gill filaments infected with Sphaerospora molnari were sampled and processed for transmission electron microscopy using cacodylate buffered osmium tetroxide as a fixative and Epon-Araldite for embedding. Double stained ultrathin sections were observed in Jeol JEM 100B electron microscope.

Results and discussion. All the parasitic cells were found intracellularly in epithelial cells of the gill filaments and secondary lamellae (Figs. 1, $2 \& 5$ ) close to developmental stages of Sphaerospora molnari. The cells, up to about $3.5 \mu \mathrm{m}$ in their largest dimension, are rounded or ellipsoidal. Their surface may be raised into stout projections (Fig. 3) or these projections may rather resemble fine villosities (Figs. $2 \& 6$ ) often seen in circular transverse sections about $2.7 \mu \mathrm{m}$ in diameter around the circumference of the cell (Fig. 4). The stages seem to be embedded directly in the cytoplasm of the host cell without eliciting formation of any parasitophorous vacuole. At higher magnification (Fig. 7) the surface appears to consist of closely superimposed unit membranes. The cytoplasm is rather dense, with numerous ribosomes and dense bodies (about $150 \mathrm{~nm}$ in diameter). The dense bodies are rounded, either homogenous or some of them (Fig. 8) have between their dense wall and dark core a more lucent layer. Except for the ribosomes and dense bodies, no cytoplasmic organelles could be discerned. The nuclei appeared rather indistinct against the background of rather dark cytoplasm. They were endowed with a distinct doublenuclear envelope. Distinct nucleoli could not be safely discerned. In some cells, a pair of nuclei closely apposed, as if forming a diplokaryon, could be seen (Figs. 3 \& 4). In other stages, a single nucleus was seen (1 of the 2 nuclei of the diplokaryon?) while in still other stages, 3 nuclei, 1 diplokaryon and a cross section of a single nucleus could be found. No division stages were encountered and no traces of transformation in other developmental sequence (e.g. sporogony).

The observed intracellular parasites are not easy to identify. From among the protozoan parasites, 3 groups come into question for possible comparison. Amoebae occur in cyprinid fish as intracellular parasites (Voelker et al. 1977, Dyková \& Lom unpubl.). They have been described to cause generalized infections, as well. However, if located intracellularly, they occur within parasitophorous vacuoles, they do have digestive vacuoles, and they do not have triplelayered cell walls. Genera of amphizoic amoebae most likely to be found in fishes (e.g. Acanthamoeba, Hartmanella, Naegleria and Vahlkampfia) do possess mitochondria. 


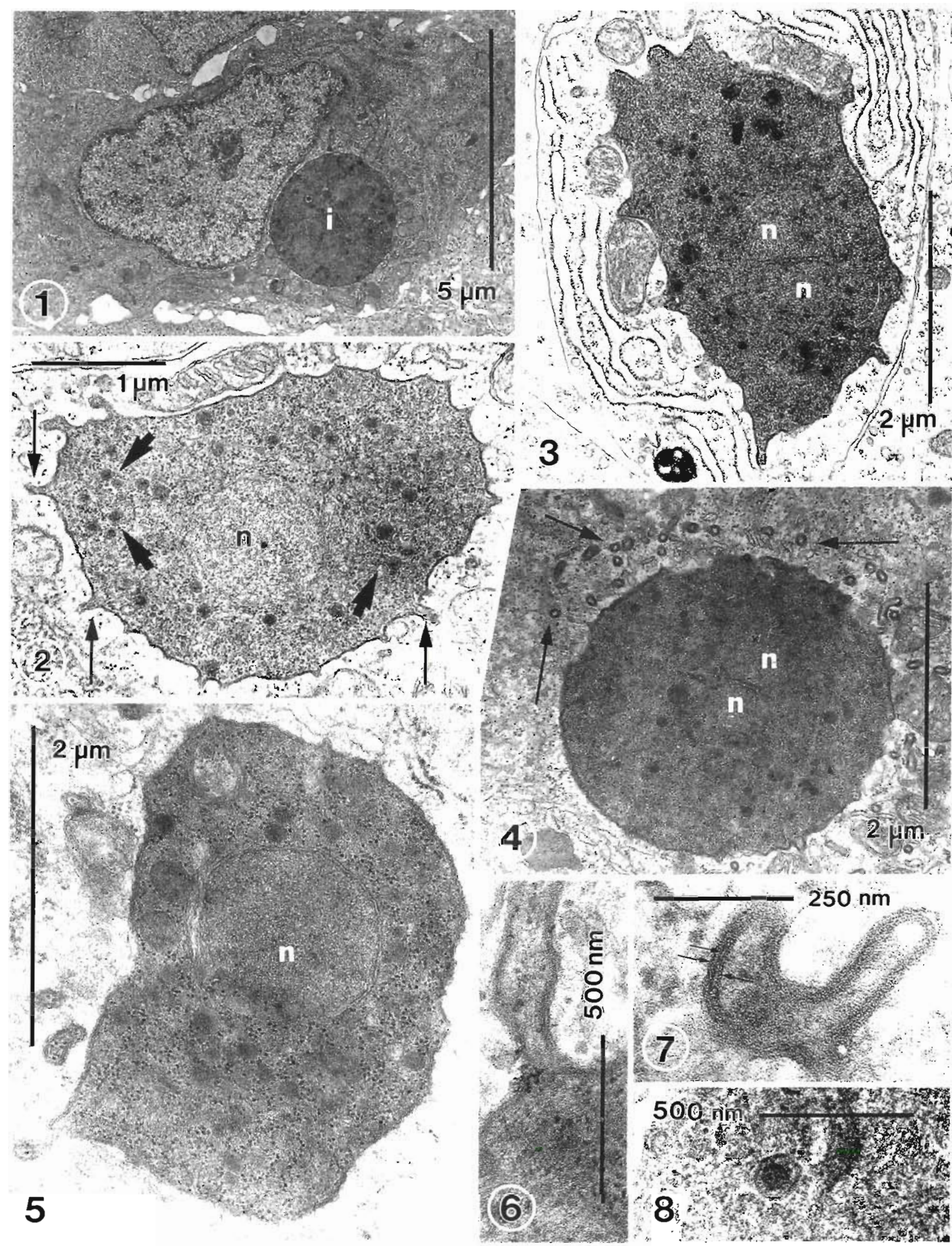

Figs 1 to 8 Parasite infecting Cyprinus carpio Fig 1 The intracellular parasite (1) next to nucleus of epithelial cell. Fig. 2. Parasite cell with microvillous projections (arrows), nucleus ( $n$ ) and dense bodies (arrowheads). Fig. 3. Parasite cell with surface raised into stout projections, 2 nuclel (n) arranged in a diplokaryon. Fig. 4. A rounded parasite cell with tubular projections seen in the host cell cytoplasm in transverse sections (arrows); n: nuclei forming a diplokaryon Fig. 5. Parasite cell with a single nucleus ( $\mathrm{n}$ ) in the level of the section with dense bodies of difterent sizes. Fig. 6. Microvillous projection extending from the cell surface. Fig. 7 Three unit membranes (arrows) covering the projection. Fig. 8. Dense body with a dark core separated from the surface by a lucent periphery 
Mitochondria are absent in microsporidia, another group with which our finding should be compared. Many microsporidian genera typically have diplokarya in their life cycle, they reveal cell projections similar to those reported here both in young meronts (e.g. in Stempellia; Desportes 1976) or sporonts (e.g. in Ovavesicula; Andreadis \& Hanula 1987). Quite often nucleoli are difficult to see in these nuclei, as well. However, microsporidian stages have mostly wellrepresented endoplasmic reticulum, while they do not have triple-layered cell wall of the type described here and lack the kind of dense inclusions that we found.

Dense inclusions are typical of haplosporidia which, however, have never been reported to occur in fishes and which do have mitochondria. In both actino- and myxosporeans, similar dense bodies (sporoplasmosomes) are found in the cytoplasm of sporoplasm. The existence of early developmental stages of myxosporean infection (Daniels et al. 1976, Markiw 1991, ElMatbouli \& Hoffmann pers. comm.) strongly suggests the possibility of myxosporean kinship. Early developmental stages of myxosporea are known to occur intracellularly (Lom \& Dyková 1992); myxosporean developmental stages do have similar surface outgrowth; diplokaryon-like arrangement of nuclei is also known in myxosporea (e.g. in Myxidium; Azevedo et al. 1989).

A serious problem, however, is posed by the absence of mitochondria. While the possibility that strange

Responsible Subject Editor: W. Körting, Hannover, Germany myxosporean developmental stages may be involved cannot be dismissed, the real identity of these parasites represents a very challenging problem and warrants further investigation.

\section{LITERATURE CITED}

Andreadis, T G., Hanula, J. L. (1987). Ultrastructural study and description of Ovavesicula popilliae n. g., n. sp. (Microsporida: Pleistophoridae) from the Japanese beetle, Popillia japonica (Coleoptera: Scarabaeidae). J. Protozool. 34: $15-21$

Azevedo, C., Lom, J., Corral, L. (1989). Ultrastructural aspects of Myxidium giardi (Myxozoa, Myxosporea), parasite of the European eel Anguilla anguilla. Dis. aquat. Org. 6: $55-61$

Daniels, S. B., Herman, R. L., Burke, C. N. (1976). Fine structure of an unidentified protozoan in the epithelium of rainbow trout exposed to water with Myxosoma cerebralis. J. Protozool 23: 402-410

Desportes, I. (1976). Ultrastructure de Stempellia mutabilis Leger et Hesse, microsporidie parasite de l'Éphémere Ephemera vulgata L. Protistologica 12: 121-150

Lom, J., Dyková, I. (1992). Protozoan parasites of fishes. Developments in aquaculture and fisheries science, Vol. 26. Elsevier, Amsterdam

Markiw, M. E. (1991). Whirling disease: earliest susceptible age of rainbow trout to the triactinomyxid of Myxobolus cerebralis. Aquaculture 92: 1-6

Voelker, F. A., Anver, M. R., McKee, A. E., Casey, H. W., Brennman, G. R. (1977). Amebiasis in goldfish. Vet. Pathol. 14: 247-255

Manuscript first received: March 22, 1993

Revised version accepted: May 3, 1993 